\title{
STRATEGI KEPALA SEKOLAH DALAM MENINGKATKAN NILAI SEMESTER SISWA UNTUK MENCAPAI ANGKA KRITERIA KETUNTASAN MINIMAL
}

\author{
Warjin Hi Soleman \\ SMP Negeri 14 Halmahera Barat Maluku Utara \\ Jalan Tahafo Kec. Ibu Kab. Halmahera Barat Prov. Maluku Utara \\ Email: soleman@gmail.com
}

\begin{abstract}
This study aims to find out the principal's strategy in increasing the students' semester score to reach the minimum criterion criteria. This research uses descriptive qualitative approach. Research location in SMP Negeri 14 West Halamahera North Maluku Province. The results showed that the principal's strategy in increasing the students' semester score to meet the minimum criteria, is: (1) the fulfillment of school infrastructure; (2) giving direction to teachers and learners with class visits; And (3) increased teacher professionalism.
\end{abstract}

Keywords: principal strategy, minimal mastery criteria

\begin{abstract}
Abstrak : Penelitian ini bertujuan untuk mengetahui strategi kepala sekolah dalam meningkatkan nilai semester siswa mencapai angka kriteria ketuntasan minimal. Penelitian ini menggunakan pendekatan kualitatif deskriptif. Lokasi penelitian di SMP Negeri 14 Halamahera Barat Provinsi Maluku Utara. Hasil penelitian menunjukkan bahwa strategi kepala sekolah dalam meningkatkan nilai semester siswa agar memenuhi kriteria minimal, yaitu: (1) pemenuhan sarana prasarana sekolah; (2) pemberian arahan kepada guru maupun peserta didik dengan kunjungan kelas; dan (3) peningkatan profisionalisme guru.
\end{abstract}

Kata kunci : strategi kepala sekolah, kriteria ketuntasan minimal

Seiring dengan derasnya tantangan global, tantangan dunia pendidikan pun semakin besar. Hal ini yang mendorong para siswa untuk bisa mendapatkan prestasi terbaik. Globalisasi sebagai bagian yang tak terpisahkan dari kehidupan modern yang semakin nyata pengaruhnya dalam mewujudkan pasar dan persaingan bebas terbuka. Lembaga pendidikan dalam keadaan seperti ini, dituntut untuk mampu menciptakan efisiensi, mengutamakan mutu, kepuasan konsumen, dan memanfaatkan peluang dengan cepat agar dapat bersaing dan bertahan. Adanya persaingan merupakan unsur yang tidak bisa ditawar lagi. Lembaga pendidikan dapat meningkatkan dan mempertahankan kualitas dengan cara membangun suatu sistem penigkatan kualitas dan menentukan standar. Kepala sekolah menjadi penentu keberhasilan sekolah, apakah dapat meningkatkan kualitas pembelajaran yang dilaksanakan guru di kelas atau tidak (Gunawan, 2015a).
Kepemimpinan pendidikan hendaknya menampilkan ciri-ciri kepemimpinan yang bersifat mendidik (Gunawan, 2015b). Kepala sekolah memiliki tanggung jawab meningkatkan kinerja paraguru di sekolahnya (Gunawan, 2015c). Peran kepala sekolah dalam menampilkan sifatsifat dan perilaku kepemimpinan menjadi faktor penentu keberhasilan sekolah dalam mencapai tujuan (Gunawan, 2016b). Guru merupakan figur sentral, di tangan gurulah terletak kemungkinan berhasil atau tidaknya pencapaian tujuan belajar mengajar di sekolah (Gunawan, 2016a). Salah satu permasalahan krusial pada sebuah lembaga pendidikan adalah ketidaktercapaian nilai siswa berdasarkan ketetapan Kriteria Ketuntasan Minimal (KKM) pada ujian semester. Ketidaktercapaian angka ketuntasan ini dapat ditelaah dari berbagai permasalahan internal maupun eksternal. 
Secara internal ada beberapa faktor yang menjadi permasalahan, yaitu: (1) man (orang) yang terdiri dari guru dan siswa, kurangnya kesiapan guru dalam menyiapkan perangkat pembelajaran sebelum proses pembelajaran dikelas, mata pelajaran yang diajarkan guru tidak sesuai dengan disiplin ilmu yang dimiliki, minat belajar siswa rendah, siswa kurang menghargai guru; (2) metode, metode pembelajaran yang kurang menarik dan tidak variatif, metode yang disajikan monoton; (3) material, guru hanya mengandalkan LKS atau hanya menggunakan satu buku rujukan dalam pembelajaran, materi yang diajarkan belum tuntas hingga pada saat pelaksanaan ujian semester; (4) mesin/sarana dan prasarana penunjang, alat peraga banyak yang rusak bahkan tidak ada, buku-buku penunjang yang kurang, ketidaktersediannya laboratorium sebagai tempat pelaksanaan praktikum mata pelajaran Ilmu Pengetahuan Alam (IPA), fasilitas internet yang kurang memadai, serta kurangnya prasarana seperti lapangan bola voli dan basket yang menjadi penyalur bakat dan minat siswa. Sedangkan faktor eksternalnya yaitu: (1) kurangnya kepedulian masyarakat terhadap lembagan pendidikan; dan (2) kepedulian orang tua terhadap keberhasilan anak yang masih minim.

Berdasarkan kajian tersebut, terdapat kesenjangan antara kondisi sekolah dengan kondisi ideal yang diharapkan sekolah. Sekolah dalam meningkatkan nilai semester siswa, melaksanakan kegiatan-kegiatan pengembangan mutu, namun semua belum dapat menyelesaikan masalah yang dihadapi sekolah. Setiap guru pasti menginginkan siswanya berhasil mencapai nilai angka ketuntasan minimal pada akhir semester, karena ketercapaian nilai siswa berdasarkan KKM menandakan bahwa siswa tersebut sudah mampu memahami keseluruhan kompetensi yang diajarkan guru selama satu semester, namun pada kenyataannya hampir sebagian besar siswa tidak mencapai angka ketuntasan minimal setiap mata pelajaran setelah mengikuti proses pembelajaran kurang lebih satu semester. Bertolak dari permasalahan dalam proses pembelajaran di sekolah tersebut, aktivitas belajar tidak dapat berjalan lancar. Kemungkinan ada saja masalah yang ditemukan, terutama masalah kesulitan belajar yang dialami peserta didik.
Keadaan ini merupakan masalah umum terjadi dalam proses belajar-mengajar, terutama dalam prinsip belajar tuntas. Di kalangan para pendidik (guru) belum ada pengertian yang baku mengenai kesulitan belajar ini. Biasanya guru akan memprediksi peserta didik yang memiliki prestasi belajar rendah, dianggap sebagai siswa yang mengalami kesulitan atau gangguan belajar. Kesulitan belajar bagi siswa bisa bermacammacam, apakah itu dalam hal menerima pelajaran, menyerap pelajaran atau keduaduanya. Setiap siswa mempunyai hak untuk mencapai prestasi belajar yang memuaskan. Namun, pada kenyataannya, setiap peserta didik memiliki perbedaan, baik perbedaan kemampuan intelektual, kemampuan fisik, latar belakang keluarga, kebiasaan, maupun pendekatan belajar yang digunakan. Perbedaan individual tersebutlah yang menyebabkan perbedaan tingkah laku belajar setiap anak. Dengan demikian, kondisi dimana siswa tidak dapat belajar sebagaimana mestinya, baik dalam menerima maupun menyerap pelajaran, inilah yang disebut sebagai kesulitan belajar. Kesulitan belajar merupakan suatu kejadian yang menunjukkan bahwa dalam mencapai tujuan pembelajaran yang telah ditetapkan, ada sejumlah peserta didik belum memahami atau menguasai secara tuntas bahan atau materi pelajaran yang disampaikan guru.

\section{METODE}

Penelitian ini bertujuan untuk menganalisis strategi kepala sekolah dalam meningkatkan nilai semester siswa untuk mencapai angka ketuntasan minimal. Ditinjau dari tujuan penelitian tersebut, penelitian ini menggunakan pendekatan kualitatif yang diarahkan pada suatu latar atau individu yang diamati secara holistik atau utuh (Ulfatin, 2015) dengan rancangan deskriptif. Metode tersebut bertujuan untuk mendeskripsikan kejadiankejadian dengan fokus penelitian. Penelitian ini termasuk jenis studi kasus, yaitu meneliti objek yang berhubungan langsung dengan strategi kepala sekolah dalam meningkatkan nilai semester siswa untuk mencapai angka ketuntasa minimal, serta mendeskripsikan secara jelas keadaan sesungguhnya di lapangan. Penelitian studi kasus memusatkan diri secara intensif pada satu obyek tertentu yang mempelajarinya sebagai suatu kasus (Gunawan, 2014). 
Penelitian ini dilakukan di SMP Negeri 14 Halmahera Barat, Jalan Trans Halmahera Kecamatan Ibu Kabupaten Halmahera Barat Provinsi Maluku Utara. Peneliti menjadi key informan (informan kunci) yang mengetahui segala sesuatu mengenai hal yang diteliti oleh peneliti. Selain itu peneliti menggunakan pihak-pihak lain untuk mendapatkan data yag dibutuhkan, yaitu kepala sekolah, wakil kepala sekolah, pendidik, serta peserta didik. Analisis data dimulai dengan mengumpulkan data, peneliti melakukan display data atau pemaparan data yang telah didapatkan peneliti di lapangan, selanjutnya data tersebut direduksi, dirangkum, dan disesuaikan dengan fokus penelitian. Setelah itu ada telaah verifikasi data dengan membuat simpulan yang diperoleh berdasarkan data yang telah direduksi

\section{HASIL}

Mengacu pada Peraturan Menteri Pendidikan dan Kebudayaan Nomor 23 Tahun 2016 tentang Standar Penilaian Pendidikan, serta visi, misi, dan tujuan sekolah, diketahui sekolah dalam meningkatkan nilai semester siswa untuk mencapai angka ketuntasan minimal belum tercapai secara optimal. Hal ini ditujukkan adanya sebagian besar siswa yang tidak mencapai angka ketuntasan minimal setelah mengikuti proses Ujian Akhir Semester (UAS) dengan indikasi antara lain adanya banyak keluhan dari wali kelas, orang tua murid, metode pembelajaran yang kurang tepat, bahan ajar yang minim, fasilitas belajar yang tidak lengkap serta kurangnya kesiapan guru ketika melaksakan pembelajaran di kelas. Pertama, adanya keluhan dari wali kelas serta orang tua murid yang menunjukkan kondisi di lapangan bahwa kemampuan meningkatkan nilai semester siswa untuk mencapai KKM belum optimal, tidak dilaksanakannya remidial, penyusunan soal belum berdasarakan kriteria yang tepat, proses pembelajaran yang kurang kondusif, penetapan KKM mata pelajaran tidak berdasarkan kriteria. Kondisi tersebut berdampak pada ketidakpuasan orang tua nilai siswa yang tidak mencapai KKM.

Kedua, metode pembelajaran yang kurang tepat. Metode yang digunakan dalam proses pembelajaran terkesan kurang menarik sehingga siswa tidak merasa tertarik terhadap apa yang dijelaskan, masalah berikutnya adalah metode pembelajaran yang disampaikan terkesan monoton, sehingga sangat menyulitkan siswa yang mempunyai tingktat pemahaman yang lemah. Ketiga, bahan ajar yang minim, guru hanya memiliki satu sumber belajar yang menjadi referensi pada saat pembelajaran, dengan memiliki sumber belajar yang kurang, maka pengetahuan yang diperoleh siswa di saat pembelajaran juga sangat terbatas, selain dari pada itu juga, materi pembelajaran belum tuntas diajarkan kepada siswa, sehingga ketika proses Ujian Akhir Semester (UAS) siswa tidak mampu menjawab soal yang di berikan guru saat diujiankan.

Keempat, fasilitas pendukung yang belum lengkap. Alat peraga banyak yang rusak (tidak bisa digunakan), perpustakaan yang tidak lengkap serta fasilitas internet yang tidak baik (gangguan jaringan) dan letak sekolah yang berdekatan dengan jalan raya, sehingga sangat menganggu proses pembelajaran di kelas. Kelima, pendidik, tenaga kependidikan, serta siswa belum mempunyai etos kerja yang tinggi, hal terindikasi bahwa guru kurang bisa memanfaatkan teknologi informasi dalam proses pembelajaran, kurangnya kesiapan guru dalam menyusun Rencana Pelaksanaan Pembelajaran (RPP) sebelum proses pembelajaran berlangsung, minat belajar siswa yang rendah serta siswa kurang menghargai guru.

Berdasarkan berbagai masalah tersebut, maka strategi kepala sekolah dalam peningkatan nilai semester siswa, yaitu: (1) pemenuhan sarana prasarana sekolah; (2) pemberian arahan kepada guru maupun peserta didik dengan kunjungan kelas; dan (3) peningkatan profisionalisme guru. Pemenuhan sarana prasarana sekolah, seperti alat peraga banyak yang rusak bahkan tidak ada, buku-buku penunjang yang kurang, ketidaktersedianya laboratorium sebagai tempat pelaksanaan praktikum mata pelajaran IPA, fasilitas internet yang kurang memadai, serta kurangnya prasarana seperti lapangan bola voli dan basket yang menjadi penyalur bakat dan minat siswa. Kepala sekolah berupaya untuk memenuhi kebutuhan sarana prasarana di sekolah terutama dalam hal kegiatan belajar mengajar di kelas, dilakukan secara menyeluruh agar pelaksanaan belajar mengajar di sekolah dapat mencapai tujuan pembelajaran serta menunjang hasil belajar peserta didik, penetapan standar pencapaian nilai untuk mencapai ketuntasan 
minimal. Ketuntasan minimal dapat diukur dari hasil penilaian kognitif.

Kepala sekolah memberikan arahan kepada guru maupun peserta didik dengan cara kepala sekolah melakukan kunjungan kelas. Adanya kunjungan kelas tersebut kepala sekolah akan mengetahui dimana letak kendala yang dialami guru maupun peserta didik dalam proses belajar di kelas. Peningkatan profisionalisme guru yang diupayakan kepala sekolah bertujuan agar para guru selalu mengikuti perkembangan teknologi dan informasi, dengan cara kepala sekolah aktif mengikutkan dirinya maupun guru dalam berbagai acara pelatihan. Acara tersebut dapat berupa pendidikan dan pelatihan bagi guru, seminar pendidikan, workshop, studi banding, kepala sekolah memberikan pendekatan kepada seluruh stakeholder dengan menggunakan pendekatan kekeluargaan. Tujuan agar tercipta suasana kekeluargaan di sekolah sehingga program-program di sekolah akan terlaksana dengan mudah.

Penyusunan perencanaan program penunjang mutu sekolah dilakukan oleh kepala sekolah bersama dewan guru dan pegawai. Kepala sekolah dan guru berkumpul bersama dalam sebuah forum untuk, menganalisis program apa saja yang dibutuhkan oleh guru dan siswa untuk meningkatkan nilai siswa dalam mencapai angka ketuntasan minimal. Perencanaan untuk menyusun program tersebut yaitu: (1) mensosialisasikan konsep program penjaminan mutu kepada seluruh warga sekolah, kepala sekolah bersama dengan staf dan seluruh guru dan karyawan bersama-sama untuk membahas program yang akan dilaksanakan; (2) melakukan analisis sasaran; (3) merumuskan sasaran didasarkan pada visi, misi dan tujuan sekolah; (4) melakukan analisis SWOT (strength, weakness, opportunity, threat); (5) menyusun rencana peningkatan mutu; dan (6) merumuskan sasaran mutu baru, dilakukan oleh kepala sekolah agar pelaksanaan dapat dilakukan secara maksimal dan dapat memberikan dampak positif terhadap peserta didik khususnya dalam meningkatkan nilai semester untuk mencapai angka ketuntasan minimal.

Langkah-langkah dalam penyusunan perencanaan program di SMP Negeri 14 Halmahera Barat, adalah: (1) melaksanakan rapat untuk membahas program yang akan dilakukan sekolah untuk menetapkan angka ketuntasan minimal pada masing-masing mata pelajaran; (2) melaksanakan kegiatan remedial; (3) melakukan pelatihan tentang cara penyusunan soal yang berstandar nasional; (4) melakuakan pelatihan tentang penggunaan teknologi informasi serta penyusuna RPP yang baik; (5) membentuk tim dan kordinator untuk bertanggung jawab untuk mengurus program yang telah dilaksanakan; dan (6) melakukan perbaikan dan pembaharuan sarana prasarana sekolah yang sesuai dengan dana yang dimiliki oleh pihak sekolah.

\section{PEMBAHASAN}

Istilah kriteria dalam penilaian sering juga disebut sebagai tolak ukur atau standar. Kriteria, tolak ukur, standar adalah sesuatu yang digunakan sebagai patokan atau batas minimal untuk sesuatu yang diukur. KKM adalah salah satu prinsip penilaian pada kurikulum berbasis kompetensi, yakni menggunakan kriteria tertentu dalam menentukan kelulusan peserta didik. Kriteria yang digunakan adalah nilai yangpaling rendah untuk menyatakan peserta didik mencapai ketuntasan. KKM lazim menggunakan sepuluh jenjang penilaian yaitu dari 1 s.d.10 atau dari 1 s.d. 100. Penetapan kriteria minimal ketuntasan belajar merupakan tahapan awal pelaksanaan penilaian hasil belajar (Arifin, 2011). In the implementation of education, assessment is a very important aspect (Retnawati, dkk., 2016).

KKM menjadi acuan bersama antara pendidik, peserta didik, dan orang tua peserta didik (Nasirullah, 2013). Namun tak jarang ditemui nilai KKM yang ditetapkan tidak dapat dipenuhi karena penyusunan dan penetapannya kurang tepat (Widodo, 2009). Fungsi pembuatan KKM adalah: (1) memudahkan evaluator (guru) dalam melakukan penilaian terhadap objek yang akandinilai karena ada patokan yang diikuti; (2) untuk menjawab dan mempertanggungjawabkan hasil penilaian yang sudah dilakukan; (3) untuk mengekang masukannya unsur subjektif yang ada pada diri penilai; (4) dengan adanya KKM, hasil evaluasi akan sama meskipun dilakukan dalam waktu yang berbeda dan dalam kondisi fisik penilai yang berbeda pula; dan (5) memberikan arahan kepada evaluator (guru) apabila evaluatornya lebih dari satu. 
Sekolah dalam penetapan nilai KKM harus melakukan analisis ketuntasan minimum pada setiap indikator, Kompetensi Dasar (KD), dan Standar Kompetensi (SK). Ketuntasan belajar ideal untuk setiap indikator adalah $1 \%$ s.d. $100 \%$, dengan batas minimal ideal minimum $75 \%$. Guru dalam menetapkan KKM harus mempertimbangkan kompleksitas, kemampuan rata-rata siswa, dan sumber daya pendukung. Tingkat kompleksitas (kerumitan dan kesulitan) setiap indikator, KD dan SK per mata pelajaran yang harus dicapai siswa. Jika tingkat kompleksitas tinggi, maka akan menuntut kemampuan berpikir tingkat tinggi, penalaran, dan kecermatan siswa. Semakin tinggi tingkat kompleksitas mata pelajaran maka semakin sulit untuk dicapai, sehingga ratarata nilainya sangat rendah. Semakin rendah tingkat kompleksitas mata pelajaran maka semakin mudah untuk dicapai sehingga rata-rata nilainya semakin tinggi.

Tingkat kemampuan (intake) rata-rata siswa pada sekolah/madrasah yang bersangkutan. Kondisi rata-rata kemampuan peserta didik dijadikan acuan standar keberhasilan pembelajaran. Semakin tinggi rata-rata kemampuan peserta didik, maka semakin mudah untuk mencapai hasil belajar sehingga nilainya sangat tinggi. Semakin rendah rata-rata kemampuan peserta didik maka semakin sulit untuk dapat mencapai sehingga nilai rata-ratanya sangat rendah. Sekolah untuk mengetahui intake peserta didik menurut Furhah (2013) dapat dilihat dari hasil ujian nasional (UN) dan juga dapat melakukan tanya jawab secara random sampling pada saat 1 minggu seusai Masa Orientasi Siswa (MOS). Acuan kriteria mengharuskan pendidik untuk melakukan tindakan yang tepat terhadap hasil penilaian, yaitu memberikan layanan remidial bagi yang belum tuntas dan atau layanan pengayaan bagi yang sudah melampaui kriteria ketuntasan minimal (Mugiono, 2011).

Kemampuan sumber daya pendukung dalam penyelenggaraan pembelajaran pada masingmasing sekolah/madrasah. Semakin tercukupi sumber daya baik yang berupa sumber daya manusia maupun yang lainnya, semakin tinggi tingkat keefektifan pembelajaran. Semakin tinggi tingkat ketercukupan dan kesesuaian daya dukung sekolah/madrasah maka semakin mudah mencapai hasil belajar sehngga nilainya sangat tinggi. Semakin rendah tingkat ketercukupan dan kesesuaian daya dukung sekolah/madrasah maka semakin sulit untuk mencapai hasil belajar yang ditetapkan sehingga rata-rata nilainya sangat rendah. Oleh sebab itu, guru harus memahami tentang taksonomi tujuan instruksional yang menyatakan adanya hierarki yang dimulai dari tujuan instruksional pada jenjang terendah sampai jenjang tertinggi (Gunawan dan Palupi, 2012).

Mulyasa (2006) menegaskan bahwa pembelajaran dikatakan berhasil dan berkualitas apabila telah mencapai $75 \%$ dari jumlah kompetensi yang disampaikan. Peserta didik harus terlibat secara aktif baik dalam fisik, mental maupun sosial dalam proses pembelajaran, serta menunjukkan semangat belajar yang besar dan percaya pada diri sendiri. KKM atau tolak ukur sebaiknya dibuat bersama dan sebaiknya dibuat oleh orang-orang yang membutuhkannya atau menggunakannya, yaitu calon evaluator, dengan maksud agar pada waktu menerapkannya tidak ada masalah karena mereka telah memahami, bahkan mengetahui apa yang melatarbelakanginya. Assessment of learning outcomes by educational units aimed at assessing the achievement of competency standards for all subjects (Kusumaningrum dan Triwiyanto, 2015). Penilaian dilakukan untuk mengetahui kemampuan akademik, bakat, dan minat calon peserta didik (Gunawan, 2017).

Kriteria ketuntasan minimal ditetapkan oleh satuan pendidikan berdasarkan hasil Musyawarah Guru Mata Pelajaran (MGMP) di satuan pendidikan atau beberapa satuan pendidikan yang memiliki karakteristik yang hampir sama. Pertimbangan pendidik atau forum MGMP secara akademis menjadi pertimbangan utama penetapan KKM. Kriteria ketuntasan menunjukkan persentase tingkat pencapaian kompetensi sehingga dinyatakan dengan angka maksimal 100 (seratus). Angka maksimal 100 merupakan kriteria ketuntasan ideal. Target ketuntasan secara nasional diharapkan mencapai minimal 75 . Satuan pendidikan dapat memulai dari kriteria ketuntasan minimal di bawah target nasional kemudian ditingkatkan secara bertahap. Keterlibatan guru dalam MGMP berhubungan secara signifikan dengan variabel kemampuan guru mengelola kelas (Gunawan dan Benty, 2007) dan akan berdampak pada kemampuan siswa untuk mencapai standar minimal dalam belajarnya. 
Penetapan KKM dilakukan oleh guru atau kelompok guru mata pelajaran. Langkah penetapan KKM adalah: (1) guru atau kelompok guru menetapkan KKM mata pelajaran dengan mempertimbangkan tiga aspek kriteria, yaitu kompleksitas. Hasil penetapan KKM indikator berlanjut pada KD, SK hingga KKM mata pelajaran; (2) hasil penetapan KKM oleh guru atau kelompok guru mata pelajaran disahkan oleh kepala sekolah untuk dijadikan patokan guru dalam melakukan penilaian; (3) KKM yang ditetapkan disosialisaikan kepada pihakpihak yang berkepentingan, yaitu peserta didik, orang tua, dan dinas pendidikan; dan (4) KKM dicantumkan dalam Laporan Hasil Belajar (LHB) pada saat hasil penilaian dilaporkan kepada orang tua/wali peserta didik. Pedoman yang selanjutnya dikenal dengan istilah KKM ini, dikonstruk dari berbagai hal yang mana hal tersebut berkaitan erat dengan faktor yang harus dilibatkan dalam mencapai kompetensi setiap mata pelajaran. Hal tersebut antara lain: tingkat kesukaran materi, sarana yang tersedia, dan kemampuan siswa.

Langkah-langkah dalam menentukan KKM adalah: (1) hitunglah jumlah KD setiap mata pelajaran setiap kelas; (2) tentukan kekuatan/ nilai untuk setiap aspek/komponen sesuai dengan kemampuan masing-masing aspek; (2) aspek kompleksitas, semakin kompleks (sukar) KD maka nilainya semakin rendah, dan semakin mudah KD maka nilainya semakin tinggi; (3) aspek sumber daya pendukung (sarana), semakin tinggi sumber daya pendukung maka nilainya semakin tinggi; (4) aspek intake, semakin tinggi kemampuan awal siswa (intake) maka nilainya semakin tinggi pula; (5) jumlah nilai setiap komponen, selanjutnya dibagi tiga untuk menentukan KKM setiap KD; (6) jumlahkan seluruh KKM KD, selanjutnya dibagi dengan jumlah KD untuk menentukan KKM mata pelajaran; dan (7) KKM setiap mata pelajaran pada setiap kelas tidak sama, tergantung pada kompleksitas KD, daya dukung, dan potensi siswa. Tabel 1 merupakan contoh penentuan KKM.
Tabel 1 Contoh Penentuan Kriteria Ketuntasan Minimal

\begin{tabular}{|l|l|l|l|l|}
\hline No & Aspek yang & \multicolumn{3}{|l|}{ Kriteria Penskoran } \\
\hline 1 & Kompleksitas & $\begin{array}{l}\text { Tinggi } \\
(1)\end{array}$ & $\begin{array}{l}\text { Sedang } \\
(2)\end{array}$ & $\begin{array}{l}\text { Rendah } \\
(3)\end{array}$ \\
\hline 2 & Daya Dukung & $\begin{array}{l}\text { Tinggi } \\
(3)\end{array}$ & $\begin{array}{l}\text { Sedang } \\
(2)\end{array}$ & $\begin{array}{l}\text { Rendah } \\
(2)\end{array}$ \\
\hline 3 & Intake siswa & $\begin{array}{l}\text { Tinggi } \\
(3)\end{array}$ & $\begin{array}{l}\text { Sedang } \\
(2)\end{array}$ & $\begin{array}{l}\text { Rendah } \\
(1)\end{array}$ \\
\hline
\end{tabular}

Berdasarkan Tabel 1 dapat disimpulkan bahwa untuk mencari KKM mata pelajaran maka seluruh KKM Standar Kompetensi (SK) dijumlahkan lalu dibagi jumlah SK yang ada, dan untuk menentukan KKM SK, maka seluruh KKM Kompetensi Dasar (KD) dijumlahkan lalu dibagi jumlah KD yang ada dan untuk menentukan KKM KD maka dijumlahkan seluruh KKM indikator kemudian dibagi dengan jumlah indikator yang ada. Berdasarkan hasil penelitian yang telah dijabarkan, dapat diketahui bahwa penyusunan program agar dapat meningkatkan nilai semester siswa mencapai KKM di SMP Negeri 14 Halamahera Barat dilakukan oleh kepala sekolah beserta guru. Perencanaan yang disusun mengacu pada 8 standar pendidikan serta visi, misi, dan tujuan sekolah. Barlian (2013) menyatakan visi kepala sekolah akan menentukan ke arah mana lembaga itu akan dibawa, karena apabila kepala sekolah tidak mempunyai visi jauh ke depan hanya akan melaksanakan tugasnya sebagai rutinitas sehari-hari, tanpa tahu kemajuan apa yang harus ia capai dalam kurun waktu tertentu.

Langkah-langkah penetapan KKM yang dilakukan sekolah tidak terlepas dari usaha kepala sekolah dalam membentuk tim untuk meningkatkan nilai semester siswa untuk mencapai angka ketuntasan minimal. Hal ini sesuai dengan pendapat Sallis (2012) yang menyatakan tim tersebut mampu menjalankan fungsi penting, mencakup: (1) bertanggung jawab pada mutu pembelajaran; (2) bertanggung jawab pada pemanfaatan waktu para guru, material serta ruang yang dimanfaatkan; (3) menjadi sarana untuk mengawasi, mengevaluasi, dan meningkatkan mutu; dan (4) bertindak sebagai penyalur informasi kepada pihak manajemen tentang perubahan-perubahan yang diperlukan dalam proses penigkatan nilai siswa untuk mencapai angka ketuntasan minimal. 


\section{Contoh Kriteria Ketuntasan Minimal}

$\begin{array}{ll}\text { Mata Pelajaran } & \text { : Kimia } \\ \text { Kelas / Semester } & : \text { X/2 } \\ \text { Sekolah } & : \text { SMP Negeri 14 } \\ & \text { Halmahera Barat }\end{array}$

Standar kompetensi: Memahami sifat-sifat larutan nonelektrolit dan elektrolit, serta reaksi oksidasi-reduksi

teknologi informasi serta penyusunan RPP yang baik.

Untuk meningkatkan nilai yang ingin dicapai berdasarkan angka ketuntasan minimal maka kepala sekolah menjalankan strategi sesuai dengan fungsinya, fungsi kepala sekolah sebagai pemimpin pendidikan mempunyai peranan yang sangat banyak untuk meningkatkan nilai semester siswa untuk mencapai angka ketuntasan minimal.

\begin{tabular}{|c|c|c|c|c|c|}
\hline \multirow[t]{2}{*}{ No } & \multirow[t]{2}{*}{ Kompetensi Dasar dan Indikator } & \multicolumn{3}{|c|}{$\begin{array}{l}\text { Kriteria Pencapaian Ketuntasan } \\
\text { Belajar Siswa (KD / Indikator) }\end{array}$} & \multirow[b]{2}{*}{ KD } \\
\hline & & Kompleksitas & $\begin{array}{l}\text { Daya } \\
\text { Dukung }\end{array}$ & $\begin{array}{l}\text { Intake } \\
\text { Siswa }\end{array}$ & \\
\hline \multirow[t]{5}{*}{$\mathbf{A}$} & $\begin{array}{l}\text { Mengidentifikasi sifat larutan } \\
\text { nonelektrolit berdasarkan data hasil } \\
\text { percobaan }\end{array}$ & & & Sodano & 88 \\
\hline & $\begin{array}{l}\text { 1. Menyimpulkan gejala-gejala hantaran } \\
\text { arus listrik dalam berbagai larutan } \\
\text { berdasarkan hasil pengamatan }\end{array}$ & (3) & (3) & (2) & \\
\hline & $\begin{array}{l}\text { 2. Mengelompokkan larutan ke dalam } \\
\text { larutan elektrolit dan nonelektrolit } \\
\text { berdasarkan sifat hantaran listriknya }\end{array}$ & $\begin{array}{l}\text { Sedang } \\
\text { (2) }\end{array}$ & $\begin{array}{l}\text { Tinggi } \\
\text { (3) }\end{array}$ & $\begin{array}{l}\text { Sedang } \\
\text { (2) }\end{array}$ & 78 \\
\hline & $\begin{array}{l}\text { 3. Menjelaskan penyebab kemampuan } \\
\text { larutan elektrolit meng-hantarkan arus } \\
\text { listrik }\end{array}$ & $\begin{array}{l}\text { Tinggi } \\
\text { (1) }\end{array}$ & $\begin{array}{l}\text { Tinggi } \\
(3)\end{array}$ & $\begin{array}{l}\text { Rendah } \\
\text { (1) }\end{array}$ & 56 \\
\hline & $\begin{array}{l}\text { 4. Menjelaskan bahwa larutan elektrolit } \\
\text { dapat berupa senyawa ion dan senyawa } \\
\text { kovalen polar }\end{array}$ & $\begin{array}{l}\text { Tinggi } \\
\text { (1) }\end{array}$ & $\begin{array}{l}\text { Tinggi } \\
\text { (3) }\end{array}$ & $\begin{array}{l}\text { Rendah } \\
\text { (1) }\end{array}$ & 56 \\
\hline
\end{tabular}

Pelaksanaan program untuk meningkatkan nilai siswa untuk mencapai angka ketuntasan minimal perlu dilakukan strategi. Strategi yang dilakukan kepala sekolah untuk meningkatkan nilai siswa dalam mencapai angka ketuntasan minimal adalah: (1) melakukan perbaikan dan pembaharuan sarana prasarana sekolah, hal ini dilakukan guna menunjang penigkatan nilai siswa untuk mencapai angka ketuntasan minimal; (2) melaksanakan kegiatan remidial, hal ini dilakukan untuk memberikan penjelasan kembali tentang materi yang belum dipahami oleh siswa; (3) pemberikan arahan kepada guru maupun peserta didik dalam pengajaran, hal ini dilakukan kepala sekolah dengan melakukan kunjungan ke kelaskelas dengan tujuan untuk melihat bagaimana proses pembelajaran yang dilakukan guru dan peserta didik; (4) meningkatkan profesionalisme guru dengan melakukan pelatihan tentang cara penyusunan soal yang berstandar nasional; dan (5) melakukan pelatihan tentang penggunaan
Fungsi kepala sekolah tersebut menurut Zulkarnain (2013) adalah: (1) membantu guru memahami, memilih, merumuskan tujuan pendidikan yang ingin dicapai sekolah secara bersama-sama yang dilakukan pada awala tahun pelajaran baru atau awal semester; (2) menggerakkan guru-guru, karyawan, siswa, dan anggota masyarakat untuk menyukseskan program-program pendidikan di sekolah; dan (3) menciptakan sekolah sebagai suatu lingkungan kerja yang harmonis, sehat, dinamis, dan nyaman, sehingga segenap anggota sekolah dapat bekerja dengan penuh produktivitas dan memperoleh kepuasan kerja yang tinggi.

Mulyasa (2013) menyatakan pengembangan guru dan staf merupakan pekerjaan yang harus dilakukan kepala sekolah dalam manajemen personalia pendidikan, yang bertujuan untuk mendayagunakan guru dan staf secara efektif dan efisien untuk mencapai hasil yang optimal. Sama halnya dengan yang dilakukan oleh Kepala SMP Negeri 14 Halmahera Barat, bahwa kepala 
sekolah aktif mengikutsertakan guru dalam kegiatan workshop dan mendorong guru untuk aktif dalam wadah MGMP. Kepala sekolah mewadahi kegiatan pendidikan tersebut guna untuk meningkatkan SDM guru dan karyawan di sekolah. Inovator dari seorang pemimpin sekolah sangat diperlukan, salah satu yang menandai pergerakan dan kemajuan lembaga pendidikan adalah seberapa besar dan banyak inovasi yang dilakukan lembaga pendidikan tersebut. Jika banyak inovasi dan pembaruan yang dilakukan, berarti terdapat kemajuan yang cukup signifikan. Tetapi sebaliknya, jika tidak banyak inovasi yang dilakukan, maka lembaga pendidikan itu akan jalan di tempat dan tidak mengalami banyak kemajuan dan perubahan (Barlian, 2013).

Langkah-langkah yang dilakukan kepala sekolah yakni melakukan pembaharuan secara terus menerus guna untuk memenuhi sarana prasarana di sekolah yang dapat menunjang kegiatan pembelajaran peserta didik di sekolah baik pembelajaran akademik maupun nonakademik yang dapat menunjang peningkatan mutu pendidikan, dan layanan pendidikan kepada peserta didik maupun seluruh karyawan di sekolah. The substance of educational activities is curriculum and learning (Kusumaningrum, dkk., 2016b). Selain itu kepala sekolah juga memberikan dorongan serta motivasi kepada guru dan peserta didik agar dapat belajar dan bekerja secara produktif di sekolah, pemenuhan sarana prasarana sesuai dengan perkembangan teknologi, sehingga seluruh warga sekolah dapat menggunakan sarana prasarana yang ada di sekolah secara maksimal. The headmaster of an educational leader has an important role in improving the quality of schools (Kusumaningrum, dkk., 2016a).

\section{KESIMPULAN DAN SARAN}

\section{Kesimpulan}

Hasil penelitian menunjukkan bahwa strategi kepala sekolah dalam meningkatkan nilai semester siswa agar memenuhi kriteria minimal, yaitu: (1) pemenuhan sarana prasarana sekolah; (2) pemberian arahan kepada guru maupun peserta didik dengan kunjungan kelas; dan (3) peningkatan profisionalisme guru. Kepala sekolah melakukan pembaharuan secara terus menerus guna untuk memenuhi sarana prasarana di sekolah yang dapat menunjang kegiatan pembelajaran peserta didik di sekolah baik pembelajaran akademik maupun nonakademik yang dapat menunjang peningkatan mutu pendidikan, dan layanan pendidikan kepada peserta didik maupun seluruh karyawan di sekolah

\section{Saran}

Berdasarkan temuan penelitian, saran yang diajukan bagi para guru adalah menetapkan KKM berdasarkan kriteria. Bagi Kepala Sekolah agar membuat data untuk memastikan bahwa setiap guru sudah menetapkan KKM sebelum memasuki semester/tahun pelajaran baru. Bagi Pengawas agar memberikan pembinaan kepada guru tentang proses penentuan KKM yang sesuai dengan dengan kriteria. Bagi peneliti lain agar melakukan penelitian lanjutan dengan memperhatikan variabel lain, sehingga akan dapat menghasilkan temuan penelitian yang komprehensif.

\section{DAFTAR RUJUKAN}

Arifin. 2011. Penetapan KKM, (Online), (http:// skp.unair.ac.id/repository/Guru-Indonesia/ PenetapanKKM_Arifin,S.Pd_10604.pdf), diakses 2 Mei 2016.

Furhah, L. 2013. Study tentang Penentuan Kriteria Ketuntasan Minimal (KKM) dan Kesesuaian Hasil Belajar Siswa Kelas VII SMP Negeri 13 Surabaya pada Mata Pelajaran Pendidikan Agama Islam, (Online), (http://digilib.uinsby. ac.id/10642/), diakses 5 Agustus 2016.

Barlian, I. 2013. Manajemen Berbasis Sekolah (Menuju Sekolah Berprestasi). Jakarta: Erlangga.

Gunawan, I., dan Benty, D. D. N. 2007. Musyawarah Guru Mata Pelajaran dan Kemampuan Mengelola Kelas untuk Meningkatkan Motivasi Belajar Siswa. Manajemen Pendidikan, 20(1), 21-31.

Gunawan, I., dan Palupi, A. R. 2012. Taksonomi Bloom - Revisi Ranah Kognitif: Kerangka Landasan untuk Pembelajaran, Pengajaran, dan Penilaian. Premiere Educandum, 2(2), 98-117.

Gunawan, I. 2014. Metode Penelitian Kualitatif: Teori dan Praktik. Jakarta: PT Bumi Aksara.

Gunawan, I. 2015a. Optimalisasi Peran dan Tugas Kepala Sekolah dalam Implementasi Kurikulum 2013. Prosiding Seminar Nasional Implementasi Kebijakan Ujian Nasional, Dualisme Kurikulum, dan Sistem Seleksi Masuk Perguruan Tinggi Negeri, Fakultas Ilmu Pendidikan Universitas Negeri Malang, Malang, 16 Mei, hlm. 23 s.d. 29. 
Gunawan, I. 2015b. Pengaruh Kepemimpinan Transformasional dan Kepuasan Kerja terhadap Perilaku Kewargaan Organisasi Guru Sekolah Dasar Negeri Kecamatan Kras Kabupaten Kediri. Premiere Educandum, 5(1), 59-81.

Gunawan, I. 2015c. Strategi Meningkatkan Kinerja Guru: Apa Program yang Ditawarkan oleh Kepala Sekolah? Prosiding Seminar Nasional Pengembangan Karir Tenaga Pendidik Berbasis Karya Ilmiah, Fakultas Ilmu Pendidikan Universitas Negeri Malang, Malang, 23 Agustus, hlm. 305-312.

Gunawan, I. 2016a. Manajemen Kelas. Malang: Penerbit UM Press.

Gunawan, I. 2016b. Pasaran: Menggali Nilai-nilai Permainan Tradisional dalam Mengembangkan Sifat-sifat Kepemimpinan Pendidikan. Jurnal Studi Sosial, 8(1), 55-64.

Gunawan, I. 2017. Manajemen Pendidikan: Suatu Pengantar Praktik. Bandung: Alfabeta.

Kusumaningrum, D. E., dan Triwiyanto, T. 2015. Review of Centralization and Decentralization Approaches to Curriculum Development in Indonesia. Proceedings International Conference on Education and Tarining (ICET), Faculty of Education, State University of Malang, Malang, November 7th, pp. 41-52.

Kusumaningrum, D. E., Sumarsono, R. B., dan Gunawan, I. 2016a. Principal Empowerment Through Soft System Methodology Approach. Proceeding International Conferences on Education and Training, 2nd ICET Theme: Improving the Quality of Education and Training Through Strengthening Networking, Faculty of Education, State University of Malang, Malang, November 4-6, pp. 205-211.

Kusumaningrum, D. E., Triwiyanto, T., dan Gunawan, I. 2016b. Educational Management of Natural Disaster Response at Lapindo Mudsidoarjo East Java. Journal of Basic and Applied Scientific Research, 6(4), 1-8.
Mugiono, M. 2011. Implementasi Kriteria Ketuntasan Minimal (KKM) di Madrasah (Studi di MTs Agung Alim Blado Kabupaten Batang), (Online), (http://repository.iainpekalongan.ac.id/54/1/ COVER\%20DLL.pdf), diakses 23 April 2016.

Mulyasa, E. 2006. Implementasi Kurukulum 2004: Panduan Belajar KBK. Bandung: Remaja Rosdakarya.

Mulyasa, E. 2013. Pengembangan dan Implementasi Kurikulum 2013. Bandung: PT Remaja Rosdakarya.

Nasirullah, M. 2013. Penetapan Nilai Kriteria Ketuntasan Minimal dengan Teknik Delphi di SMA Negeri Kabupaten Pamekasan. Jurnal Kebijakan dan Pengembangan Pendidikan, 1(1), 35-41.

Peraturan Menteri Pendidikan dan Kebudayaan Nomor 23 Tahun 2016 tentang Standar Penilaian Pendidikan, (Online), (http://bsnp-indonesia.org/ wp-content/uploads/2009/09/Permendikbud Tahun2016 Nomor023.pdf), diakses $\overline{26}$ November 2016.

Retnawati, H., Hadi, S., dan Nugraha, A. C. 2016. Vocational High School Teachers' Difficulties in Implementing the Assessment in Curriculum 2013 in Yogyakarta Province of Indonesia. International Journal of Instruction, 9(1), 33-48.

Ulfatin, N. 2015. Metode Penelitian Kualitatif di Bidang Pendidikan: Teori dan Aplikasinya. Malang: MNC Publisher.

Widodo. 2009. Mencapai Kriteria Ketuntasan Minimal dengan Bilangan Baku. Jurnal Pendidikan, 13(8), 23-28.

Zulkarnain, W. 2013. Dinamika Kelompok (Latihan Kepemimpinan Pendidikan). Jakarta: PT Bumi Aksara. 